\title{
NURSING PRACTICE AT A PSYCHIATRIC EMERGENCY SERVICE: EVALUATION USING FOURTH GENERATION ASSESSMENT ${ }^{1}$
}

\author{
Aline Aparecida Buriola², Luciane Prado Kantorski , Catarina Aparecida Sales ${ }^{4}$, Laura Misue Matsuda
}

\footnotetext{
${ }^{1}$ Result of the dissertation - Assessment of a psychiatric emergency service at a general hospital using fourth generation assessment, presented to the Graduate Nursing Program of Universidade Estadual de Maringá (UEM) in 2014.

2 Doctoral Student, Graduate Nursing Program, UEM. Faculty, undergraduate Nursing program at Universidade do Oeste Paulista. Presidente Prudente, São Paulo, Brazil. E-mail: aliburiola@bol.com.br

${ }^{3}$ Ph.D. in Nursing. Associate Professor, School of Nursing and Graduate Nursing Program at Universidade Federal de Pelotas. Pelotas, Rio Grande do Sul, Brazil. E-mail: kantorski@uol.com.br

${ }^{4}$ Ph.D. in Nursing. Faculty, Graduate Nursing Program, UEM. Maringá, Paraná, Brazil. Email: catasales@gmail.com

${ }^{5}$ Ph.D. in Nursing. Faculty, Graduate Nursing Program, UEM. Maringá, Paraná, Brazil. E-mail: lauramisuem@gmail.com
}

\begin{abstract}
Qualitative study that used the framework of Fourth Generation Assessment and aimed to apprehend the perception of professionals, users and family members, about the nurse's practice at a psychiatric emergency service. Data were collected from February to June 2014, involving with 15 professionals, nine users and six family members. In the data collection, non-participant observation, participant observation and individual interviews were held, using hermeneutic-dialectic circle, with analysis by the constant comparative method. The results were grouped into two main themes: The nurse as a facilitator of multidisciplinary and humanized care and; activity accumulation: limitation for nurses to work at the psychiatric emergency service. It was concluded that the use of Fourth Generation Assessment reveals the empowerment of stakeholders as protagonists of change and that the nurse's practice is essential for the humanization of care and the dynamics of multidisciplinary work.
\end{abstract}

DESCRIPTORS: Nursing. Emergency services, psychiatric. Nursing care. Evaluation.

\section{ATUAÇÃO DO ENFERMEIRO NO SERVIÇO DE EMERGÊNCIA PSIQUIÁTRICA: AVALIAÇÃO PELO MÉTODO DE QUARTA GERAÇÃO}

RESUMO: Estudo qualitativo que utilizou o referencial da Avaliação de Quarta Geração e que teve como objetivo apreender a percepção de profissionais, usuários e familiares, acerca da atuação do enfermeiro em um serviço de emergência psiquiátrica. Os dados foram coletados no período de fevereiro a junho de 2014, junto a 15 profissionais, nove usuários e seis familiares. Realizou-se observação não participante, observação participante e entrevista individual, por meio do círculo hermenêutico-dialético, com análise pelo método comparativo constante. Os resultados foram agrupados em dois eixos temáticos: $\mathrm{O}$ enfermeiro como facilitador do cuidado multidisciplinar e humanizado e; Acúmulo de atividades: limitação para o enfermeiro atuar no serviço de emergência psiquiátrica. Concluiu-se a que a utilização do método de Avaliação de Quarta Geração faz emergir o empoderamento dos grupos de interesse como protagonistas das transformações e que a atuação do enfermeiro é essencial para a humanização do cuidado e à dinâmica de trabalho multidisciplinar.

DESCRITORES: Enfermagem. Serviços de emergência psiquiátrica. Assistência de enfermagem. Avaliação.

\section{PRÁCTICA DE ENFERMERÍA DE URGENCIAS DE PSIQUIATRÍA: MÉTODO DE EVALUACIÓN DE CUARTA GENERACIÓN}

RESUMEN: Estudio cualitativo que utilizó el marco de Evaluación de la Cuarta Generación y que tuvo como objetivo aprehender la percepción de los profesionales, usuarios y familiares, sobre la actuación del enfermero en un servicio de urgencias psiquiátricas. Los datos fueron recolectados de febrero a junio de 2014, junto con 15 profesionales, nueve usuarios y seis miembros de la familia. En la recogida de datos se llevó a cabo la observación de no participantes, la observación de participantes y las entrevistas individuales, a través del círculo hermenéutico-dialéctico, con análisis por el método comparativo constante. Los resultados se agruparon en dos temas principales: El enfermero como facilitador del cuidado multidisciplinario y humanizado; Acumulación de Actividades: limitación para los enfermeros trabajaren en el servicio de urgencias de psiquiatría. Se concluyó que uso del método Cuarta Evaluación Generación pone de manifiesto el empoderamiento de los actores como protagonistas del cambio y la actuación del enfermero es esencial para la humanización del cuidado y la dinámica del trabajo multidisciplinario.

DESCRIPTORES: Enfermería. Servicios de urgencia psiquiátrica. Atención de enfermería. Evaluación. 


\section{INTRODUCTION}

Psychiatric emergency services (PES) set clinical and psychosocial diagnoses assertively and rapidly in situations of thought, emotional or behavioral disorders, offering quality care. ${ }^{1-2}$ Therefore, to build on the premises of deinstitutionalization, reducing the stigma and the prejudice in mental health, ${ }^{3}$ they use immediate care based on assertive orientation on the best treatment available. ${ }^{4}$

Psychiatric deinstitutionalization refers to the gradual replacement of asylum beds, through the implementation and consolidation of a Psychosocial Care Network. In Italy, where this process started, the result has influenced the consolidation of quality in mental health services, with positive repercussions for humanized care. ${ }^{5}$

To understand the relevance of psychiatric emergency services in general hospital, studies are needed that identify the perceptions of the stakeholders in the dynamics of the care process, in view of the limited production on this theme. ${ }^{4,6}$ The few studies that describe the mental health care process point towards the existence of a high care demand at emergency services, possibly compromising the quality of the health actions offered. . $^{47-8}$

Concerning the nurses' activities in PES, scientific production is even scarcer, ${ }^{9}$ mainly when considering subjective aspects, related to these professionals' activities in the institutional care system ${ }^{10-11}$; and also aspects based on the perspectives of users, professionals and family members, called stakeholders in this study.

It is known that nurses and their team represent the main workforce at hospital institutions ${ }^{12}$ in numerical terms, and that their activities, beyond care, fully focused on patients and their family, ${ }^{13}$ include actions that influence the management dynamics of health institutions. ${ }^{14}$ In that perspective, the care dynamism, intrinsic in nurses, entails a daily work burden for these professionals, which can compromise their quality of life, ${ }^{15}$ their professional relationships and even the care offered at mental health services, giving rise to conflicts that can devaluate their individual or multidisciplinary activities. ${ }^{16}$

In view of the limited discussions/publications on nursing work at PES, the following question emerges: How do stakeholders of a PES perceive the nurses' activities at this service? To answer this question, the objective in this study is to apprehend the perception of professionals, users and family members on the nurse's activities at the PES, as part of a general hospital.

\section{METHODOLOGICAL TRAJECTORY}

Case study developed at a PES of a general hospital that is a referral service in care for 45 cities. Therefore, as the theoretical-methodological base, Fourth Generation Assessment was used, ${ }^{17}$ a constructivist and responsive method within a hermeneutic-dialectical approach.

The use of case studies in fourth generation assessment research is due to its potential to describe the actual context of the object to be assessed, as well as this type of study's capacity to explore specific contexts, as it permits identifying the reality being studied and its correlation with theory and the concrete practice of the health services and programs. ${ }^{17}$

The hermeneutical-dialectical approach is hermeneutical because it permits the interpretation of the data constructed through the subjectivities; and it is dialectical because it proposes discussing different viewpoints to obtain an evaluation result that lies closer to the reality in which the opinions are produced. The responsive focus, then, uses the claims, concerns and questions of the stakeholders as aspects that guide the whole assessment process. ${ }^{17}$

Data were collected between February and June 2014 and involved 30 respondents, 15 of whom were professionals, nine were users and six were relatives, designated as stakeholders.

The following criteria were set to include the professionals: working at the service for more than six months and delivering direct care to mental disorder patients and/or their families. The criteria to include users and family members were: age 18 years or older; having used the PES at least once in the three months preceding the research; and taking part in the psychotherapy group at the mental health outpatient clinic that complements the PES.

To optimize the interviews with family members and users, the researchers chose to interview people who had previously received emergency care and who were taking part in the psychotherapy group held at the mental health outpatient clinic at the time of the research, complementing the PES. This measure was due to the fact that, during emergency psychiatric care, this type of research would be unfeasible because of its hermeneuticaldialectical method, which requires the indication of a new respondent at the end of each interview.

Users medically diagnosed with a severe or disabling mental disorder and companions who were not present when the patient was attended at the emergency service were excluded. 
To consolidate the qualitative assessment process, the data collection followed the theoretical and methodological premises of Fourth Generation assessment, summarized as follows: Contact with the field (when meetings were held with the service team, users and family members to discuss the research proposal and thus close a contract between the subjects designated as important to construct the study); Identification of the Stakeholders (in this study, the professionals, users and family members who participated in the dynamics at the psychiatric emergency service were considered); Development and expansion of the joint constructions (application of the hermeneutical-dialectical circle, identification); Presentation of the data to the stakeholders (based on the negotiation process, which consisted in the organization of each group's constructions, validation of the information and verification of consensuses). And, finally, construction of the end results of the assessment process (definition of thematic categories according to the results qualified after the negotiation).

The data collection was developed using two techniques: Non-participant observation; participant observation; and audio-recorded individual interview, established through the hermeneuticaldialectical circle.

The meeting to have contact with the place of study was held in January 2014. Next, in February of the same year, non-participant observation took place of the care dynamics established at the service, totaling 61 hours of observation, as a way to approach the research problem. Therefore, the researcher visited the place of study during the three care periods, observing freely to identify the care dynamics established at the service.

After the non-participant observation, participant observation was started, which extended from March to June 2014, totaling 152 hours. For this phase, the care aspects were observed in a more systemized manner, through immersion in the factors that were insufficiently understood during the non-participant observation. At that moment, the researcher participated actively in the care activities developed at the place study, in order to understand the care process at the service. The interview phase started in May and ended in June, when individual interviews were held with the stakeholders, taking between 45 and 75 minutes.

The interview with the first group member was guided by a semistructured interview script that contained the following questions: From your perspective, what is the psychiatric emergency service like? What are the strengths and weaknesses at this service?

The question that originated this study emerged from an emic construction of the main interviews with the stakeholders. Therefore, all respondents were also asked about "How they perceived the nurses' activities at the psychiatric emergency care service?".

It should be highlighted that the interviews were organized based on the hermeneutical-dialectical circle. For this method, the first interview started with respondent 1 , called R1 and, at the end of that person's interview, (s)he was asked to indicate another respondent, designated as R2, to be able to formulate further thoughts on the PES.

Before the interview with R2, however, the themes, concepts, ideas, values, concerns and central aspects $\mathrm{R} 1$ had proposed were summarized by listening to the audio recording of the interview, in order to extract the relevant points that made possible construction 1 (C1), which served as an information source to proceed with the interview with R2. That person was also invited, at the end of the interview, to indicate a new respondent R3.

Therefore, the interview with R2 permitted a new construction, called $\mathrm{C} 2$, which in term served to guide the interview with respondent 3 (R3) and so forth. This collection process was equally repeated in the three stakeholder groups, which were the professionals, family members and users.

As the initial respondent (R1) from the circle of professionals, the nurse with the longest experience at the service was chosen; for the users, the patient with the largest number of hospitalizations at the Emergency service; and for the family members, the person who accompanied the service user on at least two visits while interned.

For the initial analysis of the interview contents, the Constant Comparative Method ${ }^{17}$ was used, which involves analyzing the data by listening to the audio recorded testimonies soon after their collection, in order to identify each respondent's construction, and presenting the content of the preceding interviews during the further interviews with a view to new formulations on the aspects appointed during the testimonies.

It should be highlighted that the Constant Comparative Method was used merely as a e means for the immediate analysis of the data collected through the hermeneutical-dialectical cycle. For this study, the function of this cycle was to 
equip the collection of the subjective data the actors involved in the PES had presented. To justify the conciliation between these two processes, our arguments rest on the theoretical-methodological bases of Fourth Generation Assessment, ${ }^{17}$ which proposes the interaction between the two processes described.

At the end of all hermeneutical-dialectical cycles, the interviews were fully transcribed and the information resulting from the data analysis was associated with each stakeholder group and decomposed into thematic units; information units and interview fragments, highlighting the units related to the nurses' activities at the PES, which started the organization and analysis phase of the preliminary results, to be presented during the negotiation meeting in the form of thematic categories.

The negotiation phase, which served to reach consensuses on the PES and on the nurses' activities at this service, took place independently with each stakeholder group through preliminary scheduling of the date and time of the meeting, which most interviewees attended.

For this meeting, print material was produced, containing the synthesis of the interview data, delivered to each group member. Next, the researcher explained the results obtained during the interviews through a Power Point presentation, aiming to discuss, validate and negotiate on the data as the priority theme guiding the assessment.

After the negotiation phase, the data were reorganized based on the constructions and consensuses the stakeholders had established, for the sake of description in the form of thematic categories in this study. Therefore, extracts/ segments were taken, which were grammatically edited for the purpose of improving the graphical production without changing the content.

This research complied with all ethical and legal requirements set in Decree 466/12 ${ }^{18}$ and its project was registered in the Permanent Ethics Committee for Research Involving Human Beings (COPEP) of Universidade Estadual de Maringá (UEM), under opinion 23.496 and CAAE 25786714.0.0000.0104.

All participants signed two copies of the Free and Informed Consent Form. To guarantee their anonymity, excerpts from their testimonies were identified using the letter P (professional); U (user) and $F$ (family member), followed by a number that indicates the order in which the interviews were held and a summary of the subjects' characteristics.

\section{RESULTS AND DISCUSSION}

The results will be described based on two thematic categories: The nurse as a facilitator of multidisciplinary and humanized care; and Accumulation of activities: limitation for nursing work at the PES.

\section{The nurse as a facilitator of multidisciplinary and humanized care}

At the place of study, the nurses are acknowledged as articulators of the care dynamics as, due to the management competency, they direct and organize the multidisciplinary care and have easy contact with other professionals.

I think that the nurse is fundamental because nursing has something I like very much, which is organization. So, nurses are extremely important pillars because they are able to organize and attribute services in the multidisciplinary team [...] I think that the nurses still keep the service alive (P2 - psychiatrist, 30 years, four years of experience at the service).

In this testimony, it is verified that the nurses' activities are perceived as key points for the dynamics of care and that their activity mode, based on the multidisciplinary team organization, maintains the service functioning actively.

It think that the role of the nurse is excellent to come and help us. If there's any objection there in front [at the reception desk], there's any problem; they're never opposed to helping me [...]. They're the spokespersons when I get into trouble. They're always there [available], at least they are listening to us and will take it [the problem] for someone to solve [...]. (P9 receptionist, 33 years, two years and nine months of experience at the Service).

The data analysis revealed that the nurses' activities are fundamental for the appropriate management of the multidisciplinary team and in the construction process of emergency care in mental health. In the research context, it is clear that the nurses' activities are fundamental at the PES, mainly because they work in the administrative/management sphere.

In line with the above, a study developed to contextualize psychiatric nursing and mental health in Brazil ${ }^{13}$ evidenced the need for readaptations in the psychosocial care paradigm and emphasized that actions regarding nurses' activities have taken into account the local aspects that manage the care offered to mental patients and their families. This advance can be considered a response to the ap- 
proved education in psychiatry, as nurses' education allows the professionals to serve as managers in mental health care organizations.

The nurse was also appointed as a pillar for the safe execution of health actions, contact among the multidisciplinary team members, as well as because of their management capacity, which contributes to the organization of qualified and problem-solving care in health.

The nurses coordinate, they say what each person has to do with the patient, also in the containment dynamics. It is different when the nurse is there. Everything is easier, we get more trusting in what we're going to do (P15 - psychiatrist, 29 years, two years and one month of experience at the Service).

The nurse's activities at the Emergency service go beyond their role as a multidisciplinary team manager when their practice is acknowledged as a facilitator of health actions ${ }^{19}$. Nevertheless, the function as "facilitator" can also be considered a bad posture, as the nurses get burdened when they make efforts to prepare the care environment for the execution of other professionals' health actions while leaving aside their own work. ${ }^{20}$ This fact is aggravated by the lack of recognition of the nurses' activities in a complex health system, subject to situations of administrative oppression, thus consolidating hardly reflexive health practices that reproduce the biomedical model. ${ }^{14}$

To practice more reflexive and problem solving care, the health services need to prioritize the organization and safety of nursing practice, as a way to plan humanized care, acknowledging nursing work as an important social practice of care construction. ${ }^{21}$ In that context, nursing management is necessary for the quality of care, towards the promotion of service organization, the adaptation of the team; and for the organized production of health, which will certainly result in less exhaustion and better quality of care with shorter hospitalization and greater patient safety. ${ }^{22}$

The users acknowledge that bonding is constructed and welcoming health actions are promoted during nursing care.

[...] when I started to be treated in psychiatry, the nurses started to help me. I was advised to discover the reason that had taken me there [...]. It was with them [nurses] that I started to work on my psychological side. Everything got better, so I started to awake to life because that's where I received the nurses' recognition [...] (U349 years, affective bipolar mood disorder, attended twice at the service).
It can be acknowledged that the bond between the nursing team and users is the starting point for the appropriate therapeutic process, as the "help" the nursing team offers made user 3 start his internalization and behavioral change process, thus evidencing the greatness of human care in health.

The nurse's activity was also evidenced as altruistic among the family members who needed the Service, and that contributed for the family to perceive nursing care as fundamental, as shown in the following excerpt.

[...] the nurses, what they did for me was like, a rescue board because, when I was feeling really desperate about my son, we came and they helped, they took care of my son and told me to calm down that everything was going to work out. Without them, I don't know what would have happened [...] (F2 - 63 years, mother. Her son was attended at the service due to drug addiction).

F2's statement reveals that the nurses' activities at the Emergency Service allowed the families of the Service users to perceive new forms of coping with the difficulties deriving rom the mental illness and family conflicts, such as the acceptance of the mental disorder inside the family, through welcoming and humanized care.

The nurses' activities were also described as rescuing by a family member, when considering that the nursing care served as a "rescue board", presupposing that the care this professional delivered to the family was crucial to cope with the suffering the experience of having a family member in need of emergency psychiatric care entailed.

Welcoming at the moment of care is an important action the nurses perform. In one study ${ }^{7}$ that aimed to identify the nurses' approach to psychiatric patients, the care was highlighted that covers the patients' existential, relational, historical, cultural and situational dimensions, as an effective and welcoming approach to the intense mental suffering.

Besides humanized and welcoming care, the creation of bonding between the team and family of the mental patient is considered relevant, aiming to construct care based on trust and bonding, with a view to helping them to promote the changes needed to maintain mental health in the family context. ${ }^{23}$

In view of the construction professionals, users and family formulated, the relevance of the nurses at the psychiatric emergency service needs to be acknowledged, as these professionals are perceived as fundamental to achieve quality in health, mainly in services that are considered emerging in 
the context of the Brazilian psychiatric reform, like in the case of the psychiatric emergency services at general hospitals.

\section{Accumulation of activities: limitation for nursing work at the psychiatric emergency service}

Some testimonies appointed that nursing work can be compromised when the nurses are overburdened.

[...] today, the nurses' function in here is so distorted [...] they have to do so many things that I feel sorry! Really sorry [...]. We often have extremely competent employees, but they are exhausted because they do work that is not theirs. Nurses in here become social workers, aids, cleaning ladies, they do everything [...]. (P6 psychiatrist, 32 years, two years and six months of experience at the service).

The excerpt by P6 reveals the extent to which the nursing professionals have been subjugated by the burden on their shoulder, thus compromising the integral and problem-solving care proposal.

As weaknesses for the construction of qualified mental health care, it is highlighted that, in general, the nurses' activities are impaired by the structural dynamics of the service that is inappropriate to the users' demand. The excerpts from the professionals' reports support this aspect, when they refer that the nursing professionals quite frequently work at more than one sector.

The difficulties the nurses face correspond to what the literature appoints, in that the complex and crowded structural conjuncture of the health services mostly derive from the factors internal and external to the hospital structure they work in, revealing the urgent need for (re)constructions of nursing care practice. ${ }^{9,24}$

In one study that was aimed at analyzing how the conflict is manifested in interpersonal relationships and the magnitude it gains in nurses' management practice, it was verified that these professionals not always get burdened simply due to their own work, as this often happens because they assume other activities and/or roles to reduce the existing conflict in the multidisciplinary team. ${ }^{14}$

In the context related to dissatisfaction in nursing work, it is considered that this feeling derives from the complex network of factors and that, to solve it, new forms of nursing activities need to be incorporated, with a view to casting a new look on their care practice.
Rethinking the hospital model that oppresses the nurse through the accumulation of activities is emerging, mainly when it is verified that the current care dynamics, imposed daily, has impaired not only direct care delivery to patients and their family, but also the entire health team, because it does not achieve better multidisciplinary care strategies. ${ }^{25}$ According to the literature, ${ }^{15}$ this kind of facts result in low quality of life for the professionals, with high levels of dissatisfaction.

The embezzlement in the nursing staff dimensioning is a constant reality at the health services. ${ }^{12}$ Acknowledging this weakness is relevant to reflect on the direct consequences in the care process, as well as in the multidisciplinary team, which also feels burdened without the nurse. This fact can be evidenced in the following excerpt:

Their activities [nurses] here are difficult. Mainly when they have to cover two clinics. When this happens, their main care focus is not here [...] at those times, who sees what happens here are we physicians, residents and aids. Everyone is doing everything the whole time [...]. (P8 - psychiatrist, 31 years, three years of experience at the service).

The activities of nurses who are allocated at more than one clinic/sector within the same shift result in little organization of the service and an ineffective care method, which entails a burden for the entire health team. To minimize this situation, measures should be adopted for appropriate health staffing, through a System for Patient Classification and identification of the work burden, as well as resources for constant training related to safe and quality care. ${ }^{12}$

Thus, it is considered that the weakness of the mental health services' organizational structure enhances the need for discussions on the psychiatric nurse care model, as a social commitment in favor of a professional class, which has greatly suffered because of the need for human and material resources, with a view to the consolidation of qualified practice. $^{14,26}$

The health team's burden has also been appointed as an aspect that leads to the limited problem-solving ability of care delivered to the users and their families, as evidenced next:

Sometimes I think care to the family is a bit vague because, for example, sometimes, I kept waiting outside for two hours. I arrive and they say 'wait because I'm gonna talk to I don't know who' [...] I keep waiting. [...] it takes time to get back. The nurse goes and comes back in there and we stay outside, without knowing what is happening [...] I see (the nurses) entering and leaving 
from one side to the other [...]. (F1 - 49 years, mother. Her son was attended four times at the service with severe anxiety).

[...] during the night I observed that it's rare for you to meet a nurse in the corridor. I received care very quickly a nurse passed by, saw what he had to give me and went to take care of the other things. I think there should be more people there at night, because what if we get a crisis [...] (U7 - 35 years, drug addict, attended at the service four times).

The burden was also appointed as an element that causes dissatisfaction in the nurses. This particularity makes the professionals express feelings of disappointment in view of the high care demand. This argument can be observed in the following excerpt.

[...] if there weren't that much to do I think there wouldn't be that much disappointment [...] I feel so disappointed with psychiatry. The nurse is not always able to participate, do that pretty work, stay there, monitor the patient closely [...] that's why I feel really disappointed (P12 - nurse, 37 years, four years of experience at the service).

As regards the limitation of human resource, in a study ${ }^{12}$ developed based on a systematic review to identify the consequences of understaffing for the health of nursing workers, it was evidenced that the work burden and stress were the main complaints related to inappropriate staffing and that this possibly compromised the quality of the care offered.

In view of the results concerning the difficulties in nursing activities at the PES, the work burden, due to the accumulated activities, associated with the managers' limited support for appropriate nursing staffing, are factors that predispose to the inappropriateness of the nursing care process. All that reveals the need for reflections and actions that promote changes in the reality of these professionals' work.

To solve the difficult work conditions at the psychiatric services, better professional qualification is needed, associated with the nurses' autonomy for decision making, as well as appropriate staffing, according to the complexity of each health service, as strategies to improve the quality of health care. ${ }^{10,27}$ In addition, constant continuing education and the commitment of all stakeholders to scientific knowledge in mental health are needed, ${ }^{28}$ mainly concerning the family's inclusion as the focus of this knowledge and care, considering that this family suffers constantly due to the care weaknesses of the mental health services. ${ }^{29}$
In line with the above, while nursing care practice in mental health is tyrannized by the current hospital-centered model, the quality of care, especially nursing care, will be marginalized to non-problem solving tasks, directly impairing the effective implementation of the Psychiatric Reform in the Brazilian context, mainly at the new services, like the PES, inserted in general hospitals.

\section{FINAL CONSIDERATIONS}

Through this study, the stakeholders' perception on the nurses' activities at the PES was revealed. In this context, nursing care was described as essential for the organization of the care dynamics, as well as for the articulation between the multidisciplinary team and humanized care in mental health. On the opposite, the interviewees appointed that the Psychiatric Emergency Service revealed incoherence in its organizational and human resource structure, leading to a burden for the nurses and, consequently, to the weakness of the care offered. This weakness is appointed as determinant for professional dissatisfaction.

According to the findings, nurses' activities are permeated by limits and challenges, resulting from the disturbed work process they take part in. Nevertheless, their presence at the PES is fundamental for the work dynamics of the health team.

This research innovates because of the use of Fourth Generation Assessment, as this theoreticalmethodological framework, which covers constructivist research, with a formative and responsive focus, reveals the empowerment of stakeholder groups as protagonists of the changes needed to improve the Service. Through the negotiation the research method requires, proposals relevant to the stakeholder groups could be established, in terms of the appropriateness of the nurses' activities at the PES.

As a suggestion to adapt the weaknesses appointed in nursing work, the hospital managers need to be sensitized about appropriate staffing in health, especially in nursing, so as to minimize these workers' burden and dissatisfaction. One limitation in this study is the fact that the data came from a specific service, therefore permitting no generalizations.

\section{REFERENCES}

1. Brasil. Portaria 3088, de 23 de dezembro de 2011: institui a Rede de Atenção Psicossocial para pessoas com sofrimento ou transtorno mental e com necessidades decorrentes do uso de crack, álcool e outras drogas, 
no âmbito do Sistema Único de Saúde. Brasília; Diário Oficial da República Federativa do Brasil, 30 Dez 2011.

2. Page MJ, Metherall A, Hinchcliffe G. Using an accreditation scheme to demonstrate quality in mental healthcare settings. Nurs Times. 2010; 106(25):18-9.

3. Paradis M, Woogh C, Marcotte D, Chaput Y. Is psychiatric emergency service (PES) use increasing over time? Int J Ment Health Syst. 2009 Fev; 3(1):1-5.

4. Sousa FSP, Silva CAF, Oliveira EN. Serviço de Emergência Psiquiátrica em hospital geral: estudo retrospectivo. Rev Esc Enferm USP. 2010 Set; 44(3):796-802.

5. Hirdes AA. Reforma psiquiátrica no Brasil: uma (re) visão. Ciênc Saúde Coletiva. 2009 Jan-Fev; 14(1):297305.

6. Valera MR, Luciano JV, Ortiz JM, Carulla LS, Gracia A, Blanco AS. Health servisse use and costs associated with aggressiveness or agitation and containment in adult psychiatric care: a systematic review of the evidence. BMC Psychiatry. 2015; 15(35):417-21.

7. Elias ADS, Tavares CMM, Cortez EA. Nursing care of psychiatric patients in general emergency: sociopoetic inspiration. Online Braz J Nurs. 2012 Out [acesso 2015 Dez 21]; 11(Supl):424-7. Disponível em: http:/ / www.objnursing.uff.br/index.php/nursing/article/ view/3606/pdf_1

8. Kondo EH, Vilella JC, Borba LO, Paes MR, Maftum MA. A nursing team's approach to users of a mental health emergency room. Rev Esc Enferm USP. 2011 Abr; 45(2):501-7.

9. Pereira MM, Padilha MI, Oliveira AB, Santos TCF, Almeida Filho AJ, Peres MA. Discourses on the nursing and psychiatric nurse models, published in the Annals of Nursing (1933-1951). Rev Gaúcha Enferm. 2014 Jun; 35(2):47-52.

10. Lacchini AJB, Ribeiro DB, Soccol KLS, Terra MG, Silva RM. Enfermagem e a saúde mental após a reforma psiquiátrica. Rev Contexto \& Saúde. 2011 Jan-Jun; 10(20):565-8.

11. Bridges J, et al. Capacity for care: meta-ethnography of acute care nurses' experiences of the nurse-patient relationship. J Adv Nurs. 2013 Apr. 69(4):760-72.

12. Carvalho EMP, Moraes KG. Consequências do subdimensionamento de pessoal na saúde dos trabalhadores da enfermagem. Rev Eletr Gestão \& Saúde. 2013 [acesso 2015 Dez 21]; 4(4):1556-70. Disponível em: http://gestaoesaude.unb.br/index. php/gestaoesaude/article/view/687/pdf

13. Esperidião E, Silva NS, Caixeta CC, Rodrigues J. A Enfermagem Psiquiátrica, a ABEn e o Departamento Científico de Enfermagem Psiquiátrica e Saúde Mental: avanços e desafios. Rev Bras Enferm. 2013 Set; 66(spe):171-6.

14. Guerra ST, Prochnow AG, Trevizan MA, Guido LA. Conflict in the nurse managing exercise in hospital context. Rev Latino-Am Enfermagem. 2011 Mar; 19(2):362-9.
15. Inoue KC, Versa GLGS, Bellucci Júnior JA, Murassaki ACY, Matsuda LM. Qualidade de vida e no trabalho de Enfermagem: revisão integrativa da literatura. UNINGÁ Review. 2013 Out-Dez; 16(1):12-7.

16. Lapischies SRV, Jardim VMR, Kantorski LP. Satisfaction and over load of workers of community mental health services: systematic review. J Nurs UFPE online. 2013 Set [acesso 2015 Dez 21]; 7(spe):5656-67. Disponível em: http:/ / www.revista.ufpe.br/revistaenfermagem/index.php/revista/article/view/3696/pdf_3467

17. Guba EG, Lincoln YS. Avaliação de quarta geração. Campinas (SP): Unicamp; 2011.

18. Ministério da Saúde (BR), Conselho Nacional de Saúde, Comissão Nacional de Ética em Pesquisa. Resolução n. 466, de 12 de dezembro de 2012: diretrizes e normas regulamentadoras de pesquisas envolvendo seres humanos. Brasília (DF): MS; 2012.

19. Jennings N, Clifford S, Fox AR, O'Connell J, Gardner $\mathrm{G}$. The impact of nurse practitioner services on cost, quality of care, satisfaction and waiting times in the emergency department: A systematic review. Int J Nurs Stud. 2015 Jan; 52(1):421-35.

20. Thian JHM, Kannusamy P, HHG, Klainin-Yobas P. Relationships among Stress, Positive Affectivity, and Work Engagement among Registered Nurses. Psychology. 2015 Feb; 6:159-67.

21. Ulrich CM, Taylor C, Soeken K, O’Donnell P, Farrar A, Danis M, et al. Everyday ethics: ethical issues and stress in nursing practice. J Adv Nurs. 2013 Nov; 66(11):2510-9.

22. Kaufman G, McCaughan D. The effect of organizational culture on patient safety. Nurs Stand. 2013; 27(43):50-6.

23. Bessa JB, Waidman MAP. Family of people with a mental disorder and needs in psychiatric care. Texto Contexto Enferm. 2013 Jan-Mar [acesso 2015 Dez 21]; 22(1):61-70. Disponível em: http:/ / www.scielo.br/scielo.php?script=sci_arttext\&pid =S0104-07072013000100008

24. Kripalani S, Theobald CN, Anctil B, Vasilevskis EE. Reducing hospital readmission rates: current strategies and future directions. Annu Rev Med. 2014; 65:471-85.

25. Alves AP, Guidetti GECB, Diniz MA, Rezende MP, Ferreira LA, Zuffi FB. Evaluation of job impact on mental health professionals in a psychiatric institution. Rev Min Enferm. 2013 Abr-Jun; 17(2):429-8.

26. Tavares CMM, Cortez EA, Muniz MP. Cuidado no hospital psiquiátrico sob a ótica da equipe de enfermagem. Rev Rene. 2014 Mar-Abr; 15(2):282-90.

27. Silva NG, Silva PP, Oliveira AGB. A percepção dos trabalhadores de enfermagem sobre a assistência à saúde mental em hospital universitário. Cienc Cuid Saude. 2012; 11(2):302-10.

28. Mota A, Silva ALA, Souza AC. Continuing education in daily new practices in mental health: intervention research. Online Braz J Nurs. 2013 [acesso 2015 Dez 21]; 12(Supl):608-10. Disponível em: http:/ / www. 
objnursing.uff.br/index.php/nursing/article/ view/4516/html

29. Oliveira E, Mendonça J. Family member with chemical dependency and consequent burden suffered by the family: descriptive research. Online Braz J Nurs. 2012 [acesso 2015 Dez 21]; 11(1):11-7. Disponível em: http:/ / www.objnursing.uff.br/index.php/nursing/ article/view/3480/pdf_2 